\title{
Association Study of Single Nucleotide Polymorphisms in XRCC1 Gene with Risk of Hepatocellular Carcinoma in Chinese Han Population
}

\author{
Jingwang Bi, Chen Zhong, Kainan Li, Huili Chu, and Baocheng Wang \\ Department of Oncology, General Hospital of Jinan Military Region, Jinan, Shangdong 250031, China \\ Correspondence should be addressed to Jingwang Bi; jingwang_bi@sina.com
}

Received 15 May 2013; Accepted 6 July 2013

Academic Editor: Chun-Ming Wong

Copyright (C) 2013 Jingwang Bi et al. This is an open access article distributed under the Creative Commons Attribution License, which permits unrestricted use, distribution, and reproduction in any medium, provided the original work is properly cited.

\begin{abstract}
Hepatocellular carcinoma (HCC) is one of the most frequently causing cancer-related deaths worldwide. Previous evidence suggests that the X-ray repair cross-complementing group 1 gene $(X R C C 1)$ is an important candidate gene for influencing the risk of HCC. The aim of this study was to assess the association of XRCC1 genetic polymorphisms with the risk of HCC in Chinese Han population. A total of 1314 subjects, including 651 HCC patients and 663 healthy controls, were enrolled in this case-control study. Two genetic variants (c.1254C>T and c.1517G $>C$ ) in $X R C C 1$ gene were genotyped by created restriction site-polymerase chain reaction (CRS-PCR) and PCR-restriction fragment length polymorphism (PCR-RFLP) methods. Our data indicated that the allele and genotype frequencies of these two genetic variants were statistical difference in HCC cases and healthy controls. Association analyses suggested that these two genetic variants were statistically associated with the increased risk of HCC in all genetic models (for c.1254C>T, TT versus CC: OR = 2.30, 95\% CI 1.61-3.28; CT versus CC: OR =1.32, 95\% CI 1.05-1.67; TT/CT versus CC: OR = 1.50, 95\% CI 1.20-1.86; TT versus CT/CC: $\mathrm{OR}=2.00$, 95\% CI 1.43-2.80; T versus C: $\mathrm{OR}=1.47,95 \% \mathrm{CI} 1.25-1.73$; for c.1517G>C, CC versus GG: $\mathrm{OR}=1.90,95 \%$ CI 1.34-2.69; GC versus GG: OR $=1.56,95 \%$ CI $1.24-1.97$; CC/GC versus GG: $\mathrm{OR}=1.63,95 \% \mathrm{CI}$ 1.31-2.03; CC versus GC/GG: OR = 1.52, 95\% CI 1.10-2.11; C versus G: OR = 1.45, 95\% CI 1.23-1.70). The allele-T of c.1254C $>$ T and allele-C of c.1517G>C genetic variants may contribute to HCC susceptibility in Chinese Han population.
\end{abstract}

\section{Introduction}

Hepatocellular carcinoma (HCC) is the fifth common solid tumor and the third leading cause of cancer-related deaths in the world [1-3]. It is indicated that the estimated incidence of new HCC cases is approximately 500.000-1000.000 [1]. It causes 600.000 deaths globally every year [1]. Emergence evidence indicates that HCC has significantly geographical variation, and China has a very high incidence with approximately $55 \%$ of annual new cases of HCC in the world [1, 4]. Since the 1990s, HCC has been one of the most common causes of cancer-related deaths in China $[5,6]$. Many environmental factors, such as chronic hepatitis B (HBV) or hepatitis $\mathrm{C}(\mathrm{HCV})$ viral infections, alcohol consumption, cigarette smoking, and diabetes mellitus, have been evaluated the effects on HCC susceptibility [7-10], while genetic factors might play the key roles in the pathogenesis of HCC [11, 12]. To date, the exact mechanism of hepatocarcinogenesis still remains poorly understood. It has been reported that the human X-ray repair cross-complementing group 1 gene $(X R C C 1)$ is an important candidate gene influencing HCC susceptibility [13-25]. Several previous studies have been approved to evaluate the possible association between the single nucleotide polymorphisms (SNPs) in XRCC1 gene (such as arginine (Arg)194 tryptophan (Trp), Arg280 histidine (His), and Arg399 glutamssine (Gln)) and the risk of HCC [13-20]. However, the association of the c.1254C $>\mathrm{T}$ and c.1517G >C SNPs in XRCC1 gene with HCC susceptibility has not been investigated. Thus, in this case-control study, the objective of this study was to assess whether these two genetic variants influencing the susceptibility of HCC in Chinese Han population. 


\section{Materials and Methods}

2.1. Subjects. A total of 651 cases with HCC at the General Hospital of Jinan Military Region were enrolled from January 2009 to August 2012 in this study. Subjects with HCC were diagnosed by doctors based on the standards established by Chinese Society of Liver Cancer (CSLC). The control group consisted of 663 health subjects selected from health screening program participants, which have been excluded those with medical history of surgery, cancer, and other diseases. All subjects were unrelated Chinese Han nationality. The clinical characteristics, including gender, age, alcohol drinking, tobacco smoking, hypertension, diabetes mellitus, family history of HCC, serum a-FP levels, and HBV serological markers, were collected in Table 1 . This study was approved by the Institutional Ethics Committee of General Hospital of Jinan Military Region, and informed consent for participation from all subjects was obtained.

2.2. DNA Extraction and PCR Amplification. Genomic DNA was extracted from the peripheral venous blood samples using the standard method [26]. Based on the mRNA sequences (GenBank ID: NM_006297.2) and DNA sequences (GenBank ID: NC_000019.9) of human XRCC1 gene, the specific polymerase chain reaction (PCR) primers were designed by Primer Premier 5.0 software. Primers, annealing temperature, fragment size, and region are shown in Table 2. The PCR were performed in a total volume of $20 \mu \mathrm{L}$ solution containing $50 \mathrm{ng}$ template DNA, $1 \times$ buffer (Tris- $\mathrm{HCl}$ $100 \mathrm{mmol} / \mathrm{L}, \mathrm{pH} 8.3 ; \mathrm{KCl} 500 \mathrm{mmol} / \mathrm{L}), 0.25 \mu \mathrm{mol} / \mathrm{L}$ primers, $2.0 \mathrm{mmol} / \mathrm{L} \mathrm{MgCl}_{2}, 0.25 \mathrm{mmol} / \mathrm{L} \mathrm{dNTPs}$, and $0.5 \mathrm{U}$ Taq DNA polymerase (Promega, Madison, WI, USA). The PCR conditions consisted of $94^{\circ} \mathrm{C}$ for $5 \mathrm{~min}$, followed by 35 cycles of $94^{\circ} \mathrm{C}$ for 35 seconds, annealing at the corresponding temperature (shown in Table 2) for 35 seconds and $72^{\circ} \mathrm{C}$ for 35 seconds, and a final extension at $72^{\circ} \mathrm{C}$ for 5 minutes. The PCR amplified products were separated by $2.0 \%$ agarose gel electrophoresis after ethidium bromide staining and then observed under UV light.

2.3. XRCC1 Genotyping. The genotyping for c.1254C > T SNP was detected by created restriction site-PCR (CRS-PCR) method with one of the primers containing a nucleotide mismatch, which enables the use of restriction enzymes for discriminating sequence variations [27-31]. The genotyping for c.1517G >C SNP was investigated by PCR-restriction fragment length polymorphism (PCR-RFLP) method. According to the supplier's manual, aliquots of $5 \mu \mathrm{L}$ PCR amplified products were digested with $2 \mathrm{U}$ selected restriction enzyme (MBI Fermentas, St. Leon-Rot, Germany, shown in Table 2) at $37^{\circ} \mathrm{C}$ for 10 hours. The digested products were separated by electrophoresis in $2.5 \%$ agarose gel after ethidium bromide staining and observed under UV light for analyzing the XRCC1 SNPs genotyping. DNA sequencing method was done at TaKaRa Biotechnology Co., Ltd. (Dalian, China) for almost $10 \%$ of the random samples showing XRCC1 genetic polymorphisms to ensure the concordance of the results from CRS-PCR and PCR-RFLP methods.
2.4. Statistical Analysis. All statistical analyses were analyzed by the Statistical Package for Social Sciences software (SPSS, Windows version release 15.0; SPSS Inc.; Chicago, IL, USA). The chi-squared $\left(\chi^{2}\right)$ test was used to assess the HardyWeinberg equilibrium in allele and genotype frequencies and general characteristics between case and control groups. The odds ratios (ORs) and 95\% confidence intervals (95\% CIs) from multivariate logistic regression were utilized to assess the strength of associations between genetic variants of XRCC1 gene and the risk of HCC. A two-tailed significance level of $P$ less than 0.05 was defined as statistically significant for all statistical tests.

\section{Results}

3.1. General Characteristics of the Subjects. In this casecontrol study, a total of 1314 subjects were enrolled consisted of 651 HCC cases and 663 healthy controls. The results from $\chi^{2}$ test suggested that there are no significant differences between HCC cases and healthy controls with terms of age and gender distribution. As for other general characteristics of the subjects, such as smoking status and drinking consumption, diabetes mellitus, and hypertension, no significant differences were found between HCC cases and healthy controls. The general characteristics of the subjects are performed in Table 1.

3.2. Genotyping of XRCC1 SNPs. In the current study, two genetic variants (c.1254C $>\mathrm{T}$ and c.1517G $>C$ ) could be genotyped by CRS-PCR and PCR-RFLP methods, respectively, and confirmed by DNA sequencing. According to the DNA sequence analysis, the $c .1254 \mathrm{C}>\mathrm{T}$ genetic variant is a synonymous mutation, which caused by $\mathrm{C}$ to $\mathrm{T}$ mutations in exon 11 of human XRCC1 gene (p-serine (Ser) 418Ser). As for $\mathrm{c} .1517 \mathrm{G}>\mathrm{C}$, this genetic variant is nonsynonymous mutation, which caused by $\mathrm{G}$ to $\mathrm{C}$ mutations in exon 14 of human XRCC1 gene and led to the glycine (Gly) to alanine (Ala) amino acid replacement (p.Gly506Ala, Reference sequences GenBank IDs: NC_000019.9, NM_006297.2, and NP_006288.2). The PCR amplified products of c.1254C $>\mathrm{T}$ were digested with $\mathrm{HpaII}$ restriction enzyme and divided into three genotypes, CC (195 and $23 \mathrm{bp})$, CT (218, 195, and $23 \mathrm{bp}$ ), and TT (218 bp). The PCR amplified products of c.1517G>C were digested with HaeIII restriction enzyme and divided into three genotypes, GG (247 bp), GA (247, 168, and $79 \mathrm{bp})$, and AA (168, and $79 \mathrm{bp}$, Table 2).

3.3. Allele and Genotype Frequencies. The observed genotype frequencies of $c .1254 \mathrm{C}>\mathrm{T}$ and $\mathrm{c} .1517 \mathrm{G}>\mathrm{C}$ genetic variants sites were corresponded to Hardy-Weinberg equilibrium in both of HCC cases and controls $(P>0.05$, Table 3$)$. Table 3 shows the allelic and genotypic frequencies of these two genetic variants. The C-allele of c.1254C>T and G-allele of c.1517G $>\mathrm{C}$ genetic variants were predominant alleles in the studied subjects. As for c.1254C $>\mathrm{T}$, significantly differences were detected between the allele frequencies of HCC cases (C, 61.06\%; T, 38.94\%) and those of the healthy controls (C, 69.76\%; T, 30.24\%, $\chi^{2}=21.9827, P<0.001$ ), and the genotypic frequencies in HCC cases were statistically 
TABLE 1: Clinical characteristics of hepatocellular carcinoma (HCC) cases and controls.

\begin{tabular}{|c|c|c|c|c|c|c|}
\hline Characteristics & Cases $(n)$ & $\%$ & Controls $(n)$ & $\%$ & $\chi^{2}$ value & $P$ value \\
\hline Number & 651 & & 663 & & & \\
\hline Gender $(n)$ & & & & & 0.6900 & 0.4062 \\
\hline Male & 389 & 59.75 & 411 & 61.99 & & \\
\hline Female & 262 & 40.25 & 252 & 38.01 & & \\
\hline \multicolumn{7}{|l|}{ Age (years) } \\
\hline Mean \pm SD & \multicolumn{2}{|c|}{$58.69 \pm 12.45$} & \multicolumn{2}{|c|}{$59.17 \pm 13.22$} & 2.8181 & 0.0932 \\
\hline$<55$ & 365 & 56.07 & 402 & 60.63 & & \\
\hline$\geq 55$ & 286 & 43.93 & 261 & 39.37 & & \\
\hline Alcohol drinking & & & & & 2.3325 & 0.1267 \\
\hline Yes & 332 & 51.00 & 366 & 55.20 & & \\
\hline No & 319 & 49.00 & 297 & 44.80 & & \\
\hline Tobacco smoking & & & & & 0.8282 & 0.3628 \\
\hline Yes & 349 & 53.61 & 372 & 56.11 & & \\
\hline No & 302 & 46.39 & 291 & 43.89 & & \\
\hline Hypertension $(n)$ & & & & & 0.1742 & 0.6764 \\
\hline Yes & 115 & 17.67 & 123 & 18.55 & & \\
\hline No & 536 & 82.33 & 540 & 81.45 & & \\
\hline Diabetes mellitus $(n)$ & & & & & 1.0300 & 0.3102 \\
\hline Yes & 121 & 18.59 & 138 & 20.81 & & \\
\hline No & 530 & 81.41 & 525 & 79.19 & & \\
\hline \multicolumn{7}{|c|}{ Family history of HCC $(n)$} \\
\hline Yes & 48 & 7.37 & - & & & \\
\hline No & 603 & 92.63 & - & & & \\
\hline \multicolumn{7}{|l|}{ Serum a-FP levels } \\
\hline$<400 \mathrm{ng} / \mathrm{mL}$ & 206 & 31.64 & - & & & \\
\hline$>400 \mathrm{ng} / \mathrm{mL}$ & 445 & 68.36 & - & & & \\
\hline \multicolumn{7}{|c|}{ HBV serological markers $(n)$} \\
\hline HBs Ag (+) & 131 & 20.12 & - & & & \\
\hline HBs Ag $(-)$ & 520 & 79.88 & - & & & \\
\hline
\end{tabular}

TABLE 2: Primers, PCR-RFLP, and CRS-PCR analyses for genotyping XRCC1 gene polymorphisms.

\begin{tabular}{|c|c|c|c|c|c|c|}
\hline SNPs & Primer sequences & $\begin{array}{c}\text { Annealing } \\
\text { temperature }\left({ }^{\circ} \mathrm{C}\right)\end{array}$ & $\begin{array}{l}\text { Amplification } \\
\text { fragment (bp) }\end{array}$ & Region & $\begin{array}{c}\text { Restriction } \\
\text { enzyme }\end{array}$ & Genotype (bp) \\
\hline c. $1254 \mathrm{C}>\mathrm{T}$ & $\begin{array}{l}5^{\prime} \text {-GAGGAGGATGAGGCCTCTCACAC- } 3^{\prime} \\
5^{\prime} \text {-TAAGGAGGGAGAGTGGGTGGGT-3 }\end{array}$ & 63.9 & 218 & Exon11 & HраII & $\begin{array}{l}\text { CC: } 195,23 \\
\text { CT: } 218,195,23 \\
\text { TT: } 218\end{array}$ \\
\hline c. $1517 \mathrm{G}>\mathrm{C}$ & $\begin{array}{l}5^{\prime} \text {-CAAGTCCCAGCTGAGAACTGAG-3' } \\
5^{\prime} \text {-GCTGCTCTGCATGCTCACTC-3' }\end{array}$ & 59.0 & 247 & Exon14 & HaeIII & $\begin{array}{l}\text { GG: } 247 \\
\text { GC: } 247,168,79 \\
\text { CC: } 168,79\end{array}$ \\
\hline
\end{tabular}

Note: PCR means polymerase chain reaction; PCR-RFLP means PCR-restriction fragment length polymorphism; CRS-PCR means created restriction site PCR; SNPs mean single nucleotide polymorphisms. Underlined nucleotides mark nucleotide mismatches enabling the use of the selected restriction enzymes for discriminating sequence variations.

significant different from those of healthy controls $\left(\chi^{2}=\right.$ 22.3180, $P<0.001$, Table 3). Similarly, as for c.1517G $>$ C, significantly differences were found between the allele frequencies of HCC cases (G, 61.29\%; C, 38.71\%) and those of the healthy controls (G, 69.61\%; C, 30.39\%, $\chi^{2}=20.1085$, $P<0.001)$, and the genotypic frequencies in HCC cases were statistically significant different from those of healthy controls $\left(\chi^{2}=20.3680, P<0.001\right.$, Table 3$)$.
3.4. Association between XRCC1 SNPs and HCC Risk. Table 4 presents the association between XRCC1 SNPs and the risk of HCC. As for c.1254C>T, there were statistically increased risk of HCC in the homozygote comparison (TT versus CC: $\mathrm{OR}=2.30,95 \%$ CI 1.61-3.28, $\left.\chi^{2}=21.59, P<0.001\right)$, heterozygote comparison (CT versus CC: $\mathrm{OR}=1.32,95 \%$ CI 1.05-1.67, $\left.\chi^{2}=5.58, P=0.018\right)$, dominant model (TT/CT versus CC: $\mathrm{OR}=1.50,95 \%$ CI $1.20-1.86, \chi^{2}=12.96$, 


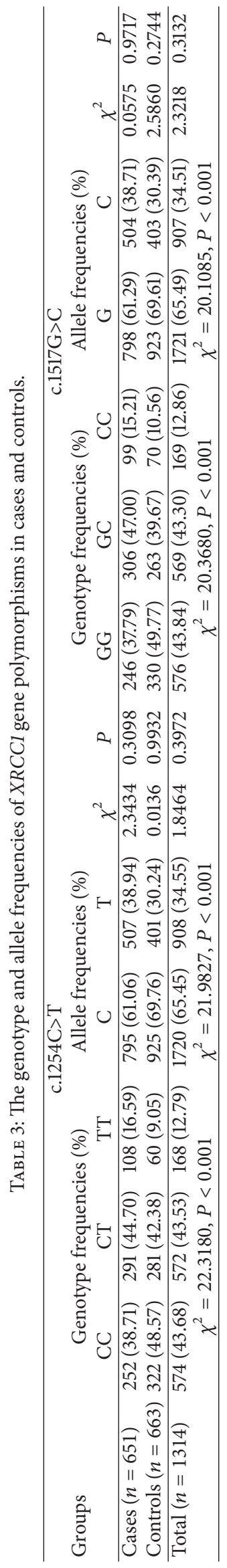


TABLE 4: Association between hepatocellular carcinoma (HCC) risk and XRCC1 gene polymorphisms.

\begin{tabular}{|c|c|c|c|c|}
\hline \multirow{2}{*}{ SNPs } & \multirow{2}{*}{ Comparisons } & \multicolumn{3}{|c|}{ Test of association } \\
\hline & & OR (95\% CI) & $\chi^{2}$ value & $P$ value \\
\hline \multirow{5}{*}{ c. $1254 \mathrm{C}>\mathrm{T}$} & Homozygote comparison (TT vs. CC) & $2.30(1.61-3.28)$ & 21.59 & $\overline{<0.001}$ \\
\hline & Heterozygote comparison (CT vs. CC) & $1.32(1.05-1.67)$ & 5.58 & 0.018 \\
\hline & Dominant model (TT/CT vs. CC) & $1.50(1.20-1.86)$ & 12.96 & $<0.001$ \\
\hline & Recessive model (TT vs. CT/CC) & $2.00(1.43-2.80)$ & 16.73 & $<0.001$ \\
\hline & Allele contrast (T vs. C) & $1.47(1.25-1.73)$ & 21.97 & $<0.001$ \\
\hline \multirow{5}{*}{ c. $1517 \mathrm{G}>\mathrm{C}$} & Homozygote comparison (CC vs. GG) & $1.90(1.34-2.69)$ & 13.22 & $<0.001$ \\
\hline & Heterozygote comparison (GC vs. GG) & $1.56(1.24-1.97)$ & 14.04 & $<0.001$ \\
\hline & Dominant model (CC/GC vs. GG) & $1.63(1.31-2.03)$ & 19.15 & $<0.001$ \\
\hline & Recessive model (CC vs. GC/GG) & $1.52(1.10-2.11)$ & 6.33 & 0.012 \\
\hline & Allele contrast (C vs. G) & $1.45(1.23-1.70)$ & 20.10 & $<0.001$ \\
\hline
\end{tabular}

SNPs: single nucleotide polymorphisms; OR: odds ratio; CI: confidence interval; vs.: versus.

$P<0.001$ ), recessive model (TT versus CT/CC: $\mathrm{OR}=2.00$, 95\% CI 1.43-2.80, $\left.\chi^{2}=16.73, P<0.001\right)$, and allele comparison (T versus C: $\mathrm{OR}=1.47,95 \%$ CI $1.25-1.73, \chi^{2}=21.97$, $P<0.001)$. As for c.1517G $>$ C, significantly increased risk of HCC was found in the homozygote comparison (CC versus GG: $\mathrm{OR}=1.90,95 \%$ CI 1.34-2.69, $\left.\chi^{2}=13.22, P<0.001\right)$, heterozygote comparison (GC versus GG: OR $=1.56,95 \% \mathrm{CI}$ 1.24-1.97, $\left.\chi^{2}=14.04, P<0.001\right)$, dominant model (CC/GC versus $\left.\mathrm{GG}: \mathrm{OR}=1.63,95 \% \mathrm{CI} 1.31-2.03, \chi^{2}=19.15, P<0.001\right)$, recessive model (CC versus GC/GG: $\mathrm{OR}=1.52$, 95\% CI 1.102.11, $\chi^{2}=6.33, P=0.012$ ), and allele comparison ( $\mathrm{C}$ versus $\mathrm{G}: \mathrm{OR}=1.45,95 \%$ CI $\left.1.23-1.70, \chi^{2}=20.10, P<0.001\right)$.

\section{Discussion}

It is general accepted that HCC is a common primary malignant liver cancer causing by complex interactions between genetic and environmental factors [7, 32-34]. There were several studies indicated that the genotypic variation plays key roles in human phenotypic variability for HCC susceptibility. The XRCC1 gene is one of the most important candidate genes for HCC, and the association between several SNPs in XRCC1 gene such as Arg194Trp, Arg280His and Arg399Gln and the risk of HCC have been assessed in recent years [13-20]; however, the results from these observations still remain conflicting rather than conclusive. Kiran et al. demonstrated that Arg194Trp, Arg280His, and Arg399Gln SNPs were significantly associated with the risk of hepatitis virus-related HCC in Indian population [16]. Pan et al. reported that the Arg399Cln Arg/Gln indicated an increased risk of HCC, especially for patients above 50 years old or with drinking habits in Chinese population [17]. Liu et al. indicated that the Arg399Gln is not associated with altered HCC susceptibility [21]. In the present study, on the basis of analysis of 651 HCC patients and 663 healthy control subjects, we detected the c.1254C $>\mathrm{T}$ and c.1517G $>\mathrm{C}$ SNPs of XRCC1 gene by PCR-RFLP, CRS-PCR, and DNA sequencing methods. We demonstrated that these two SNPs have statistically significant impacts on the susceptibility to HCC in Chinese Han population (Table 4). Our data suggested that the significant difference were shown in the allelic and genotypic frequencies between HCC patients and healthy controls for these two SNPs (Table 3). As for c.1254C>T, the TT genotype was statistically associated with the increased susceptibility of developing HCC compared to CC genotype and CT/CC carriers (all $P<0.001$ ). As for $c .1517 \mathrm{G}>\mathrm{C}$, the CC genotype was statistically associated with the increased susceptibility of developing HCC compared to GG genotype and GC/GG carriers (all $P<0.001$ ). Therefore, the T-allele of c.1254C>T and the C-allele of c.1517G $>\mathrm{C}$ genetic variants may contribute to the susceptibility of HCC $(P<0.001$, Table 4$)$. To the best of our knowledge, this is the first report regarding the association between c.1254C $>$ T and c.1517G $>$ C SNPs and the risk of HCC. Our data indicated that these two genetic variants were significantly associated with the increased susceptibility of HCC in Chinese Han population. The findings could provide new evidence for further analysis of the biological function role of $X R C C 1$ gene variants on the susceptibility of HCC carcinogenesis. Larger prospective investigations will be essential to confirm these results on different populations and explain the underlying molecular mechanism.

\section{Conflict of Interests}

The authors declare that they have no conflict of interests.

\section{Authors' Contribution}

Jingwang Bi and Chen Zhong have contributed equally to this paper.

\section{References}

[1] D. M. Parkin, F. Bray, J. Ferlay, and P. Pisani, "Global cancer statistics, 2002," CA: A Cancer Journal for Clinicians, vol. 55, no. 2, pp. 74-108, 2005.

[2] J. M. Llovet, A. Burroughs, and J. Bruix, "Hepatocellular carcinoma," The Lancet, vol. 362, no. 9399, pp. 1907-1917, 2003.

[3] S. Parikh and D. Hyman, "Hepatocellular cancer: a guide for the internist," American Journal of Medicine, vol. 120, no. 3, pp. 194202, 2007.

[4] K. Schütte, J. Bornschein, and P. Malfertheiner, "Hepatocellular carcinoma-epidemiological trends and risk factors," Digestive Diseases, vol. 27, no. 2, pp. 80-92, 2009. 
[5] J.-G. Chen, S.-W. Zhang, and W.-Q. Chen, "Analysis of liver cancer mortality in the national retrospective sampling survey of death causes in China, 2004-2005," Zhonghua Yu Fang Yi Xue Za Zhi, vol. 44, no. 5, pp. 383-389, 2010.

[6] X. Zeng, S. Liu, H. Yu et al., "DNA repair capacity, DNAstrand break repair gene polymorphisms, and the incidence of hepatocellular carcinoma in southwestern Guangxi of China," DNA and Cell Biology, vol. 31, no. 8, pp. 1384-1391, 2012.

[7] P. A. Farazi and R. A. DePinho, "Hepatocellular carcinoma pathogenesis: from genes to environment," Nature Reviews Cancer, vol. 6, no. 9, pp. 674-687, 2006.

[8] A. Suriawinata and R. Xu, "An update on the molecular genetics of hepatocellular carcinoma," Seminars in Liver Disease, vol. 24, no. 1, pp. 77-88, 2004.

[9] F. X. Bosch, J. Ribes, M. Díaz, and R. Cléries, "Primary liver cancer: worldwide incidence and trends," Gastroenterology, vol. 127, no. 5, supplement 1, pp. S5-S16, 2004.

[10] A. I. Gomaa, S. A. Khan, M. B. Toledano, I. Waked, and S. D. Taylor-Robinson, "Hepatocellular carcinoma: epidemiology, risk factors and pathogenesis," World Journal of Gastroenterology, vol. 14, no. 27, pp. 4300-4308, 2008.

[11] J.-C. Nault and J. Zucman-Rossi, "Genetics of hepatobiliary carcinogenesis," Seminars in Liver Disease, vol. 31, no. 2, pp. 173187, 2011.

[12] S. S. Thorgeirsson and J. W. Grisham, "Molecular pathogenesis of human hepatocellular carcinoma," Nature Genetics, vol. 31, no. 4, pp. 339-346, 2002.

[13] A. R. B. Rossit, I. R. Cabral, C. Hackel, R. da Silva, N. D. Froes, and S. Z. Abdel-Rahman, "Polymorphisms in the DNA repair gene $X R C C 1$ and susceptibility to alcoholic liver cirrhosis in older Southeastern Brazilians," Cancer Letters, vol. 180, no. 2, pp. 173-182, 2002.

[14] M.-W. Yu, S.-Y. Yang, I.-J. Pan et al., "Polymorphisms in XRCC1 and glutathione S-transferase genes and hepatitis B-related hepatocellular carcinoma," Journal of the National Cancer Institute, vol. 95, no. 19, pp. 1485-1488, 2003.

[15] M. Kiran, Y. K. Chawla, M. Jain, and J. Kaur, "Haplotypes of microsomal epoxide hydrolase and X-ray cross-complementing group 1 genes in indian hepatocellular carcinoma patients," DNA and Cell Biology, vol. 28, no. 11, pp. 573-577, 2009.

[16] M. Kiran, R. Saxena, Y. K. Chawla, and J. Kaur, "Polymorphism of DNA repair gene XRCC1 and hepatitis-related hepatocellular carcinoma risk in Indian population," Molecular and Cellular Biochemistry, vol. 327, no. 1-2, pp. 7-13, 2009.

[17] H. Z. Pan, J. Liang, Z. Yu, L. M. Lun, H. Li, and Q. Wang, "Polymorphism of DNA repair gene XRCC1 and hepatocellular carcinoma risk in Chinese population," The Asian Pacific Journal of Cancer Prevention, vol. 12, pp. 2947-2950, 2011.

[18] Q. W. Li, C. R. Lu, M. Ye, W. H. Xiao, and J. Liang, "Evaluation of DNA repair gene XRCC1 polymorphism in prediction and prognosis of hepatocellular carcinoma risk," Asian Pacific Journal of Cancer Prevention, vol. 13, no. 1, pp. 191-194, 2012.

[19] X. Han, Q. Xing, Y. Li et al., "Study on the DNA repair gene $X R C C 1$ and XRCC3 polymorphism in prediction and prognosis of hepatocellular carcinoma risk," Hepato-Gastroenterology, vol. 59, no. 119, pp. 2285-2289, 2012.

[20] X. D. Long, Y. Ma, H. D. Hong, J. G. Yao, D. Y. Qu, and Y. L. $\mathrm{Lu}$, "Polymorphism of XRCC1 and the frequency of mutation in codon 249 of the p53 gene in hepatocellular carcinoma among Guangxi population, China," Molecular Carcinogenesis, vol. 47, no. 4, pp. 295-300, 2008.
[21] F. Liu, B. Li, Y. Wei et al., "XRCC1 genetic polymorphism Arg399Gln and hepatocellular carcinoma risk: a meta-analysis," Liver International, vol. 31, no. 6, pp. 802-809, 2011.

[22] P. Borentain, V. Gérolami, P. Ananian et al., "DNA-repair and carcinogen-metabolising enzymes genetic polymorphisms as an independent risk factor for hepatocellular carcinoma in Caucasian liver-transplanted patients," European Journal of Cancer, vol. 43, no. 17, pp. 2479-2486, 2007.

[23] X. D. Long, Y. Ma, Y. P. Wei, and Z. L. Deng, “The polymorphisms of GSTM1, GSTT1, HYL1* 2, and XRCC1, and aflatoxin B1-related hepatocellular carcinoma in Guangxi population, China," Hepatology Research, vol. 36, no. 1, pp. 48-55, 2006.

[24] C.-C. Chen, S.-Y. Yang, C.-J. Liu et al., "Association of cytokine and DNA repair gene polymorphisms with hepatitis B-related hepatocellular carcinoma," International Journal of Epidemiology, vol. 34, no. 6, pp. 1310-1318, 2005.

[25] G. D. Kirk, P. C. Turner, Y. Gong et al., "Hepatocellular carcinoma and polymorphisms in carcinogen-metabolizing and DNA repair enzymes in a population with aflatoxin exposure and hepatitis B virus endemicity," Cancer Epidemiology Biomarkers and Prevention, vol. 14, no. 2, pp. 373-379, 2005.

[26] A. K. Daly, V. M. Steen, K. S. Fairbrother, and J. R. Idle, "CYP2D6 multiallelism," Methods in Enzymology, vol. 272, pp. 199-210, 1996.

[27] A. Haliassos, J. C. Chomel, L. Tesson et al., "Modification of enzymatically amplified DNA for the detection of point mutations," Nucleic Acids Research, vol. 17, no. 9, p. 3606, 1989.

[28] Z. R. Yuan, J. Li, J. Y. Li, X. Gao, and S. Z. Xu, "SNPs identification and its correlation analysis with milk somatic cell score in bovine MBL1 gene," Molecular Biology Reports, vol. 40, pp. 7-12, 2013.

[29] Z. R. Yuan, J. Y. Li, J. Li et al., "Investigation on BRCA1 SNPs and its effects on mastitis in Chinese commercial cattle," Gene, vol. 505, pp. 190-194, 2012.

[30] Z. R. Yuan, J. Y. Li, J. Li, X. Gao, and S. Z. Xu, "Effects of DGAT1 gene on meat and carcass fatness quality in Chinese commercial cattle," Molecular Biology Reports, vol. 40, pp. 1947-1954, 2013.

[31] C. J. Zhao, N. Li, and X. M. Deng, "The establishment of method for identifying SNP genotype by CRS-PCR," Yi Chuan, vol. 25, no. 3, pp. 327-329, 2003.

[32] H. B. El-Serag and K. L. Rudolph, "Hepatocellular carcinoma: epidemiology and molecular carcinogenesis," Gastroenterology, vol. 132, no. 7, pp. 2557-2576, 2007.

[33] D. N. Amarapurkar, N. D. Patel, and P. M. Kamani, "Impact of diabetes mellitus on outcome of HCC," Annals of Hepatology, vol. 7, no. 2, pp. 148-151, 2008.

[34] J. A. Marrero, R. J. Fontana, S. Fu, H. S. Conjeevaram, G. L. Su, and A. S. Lok, "Alcohol, tobacco and obesity are synergistic risk factors for hepatocellular carcinoma," Journal of Hepatology, vol. 42, no. 2, pp. 218-224, 2005. 


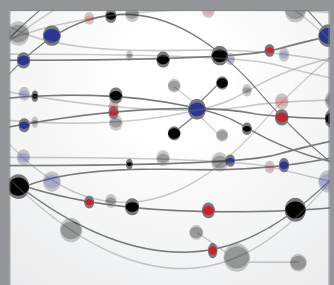

The Scientific World Journal
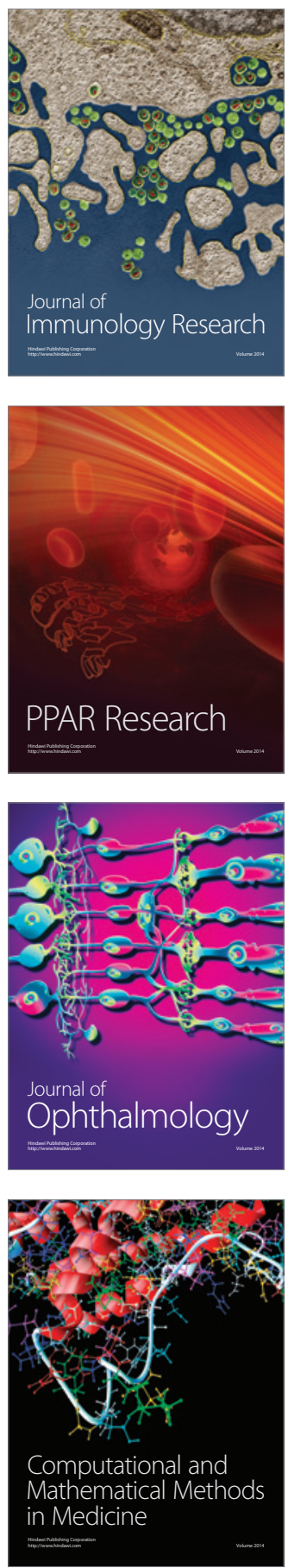

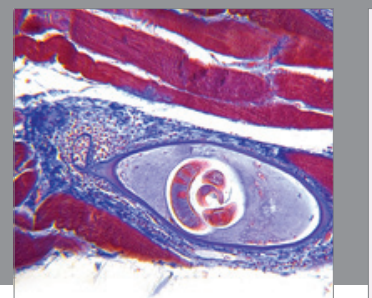

Gastroenterology

Research and Practice
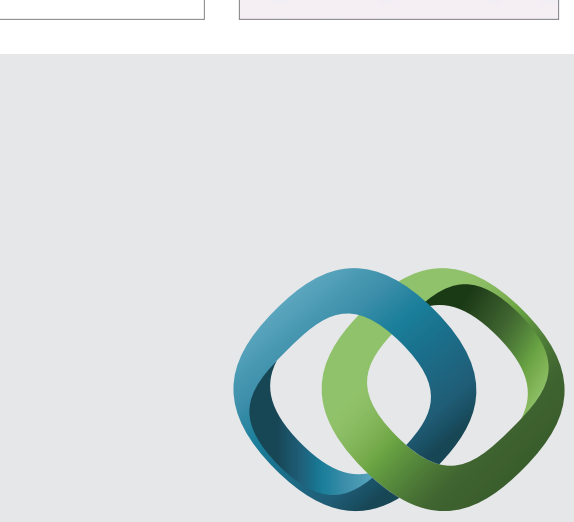

\section{Hindawi}

Submit your manuscripts at

http://www.hindawi.com
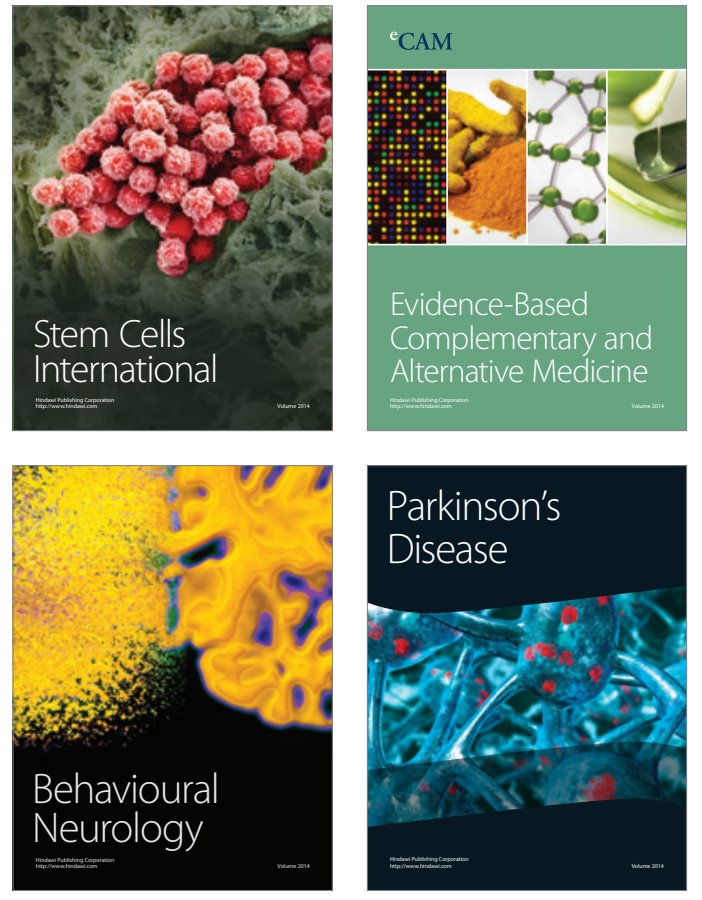
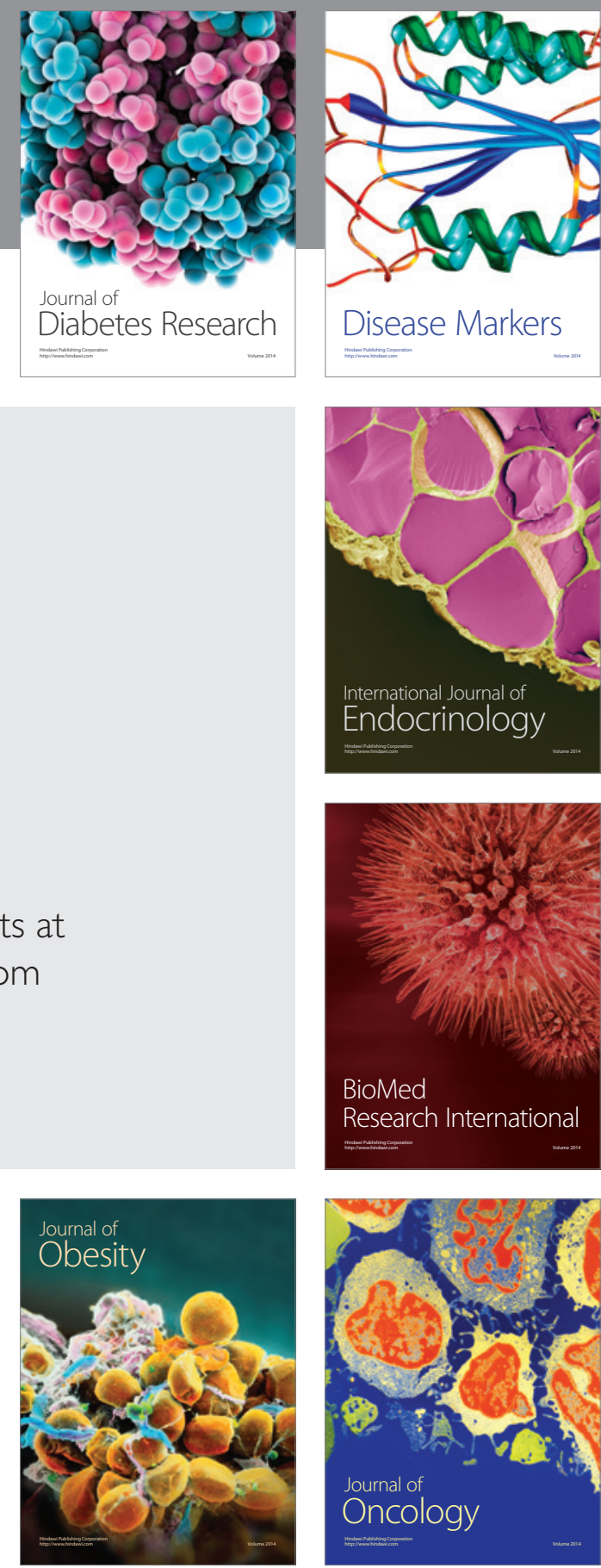

Disease Markers
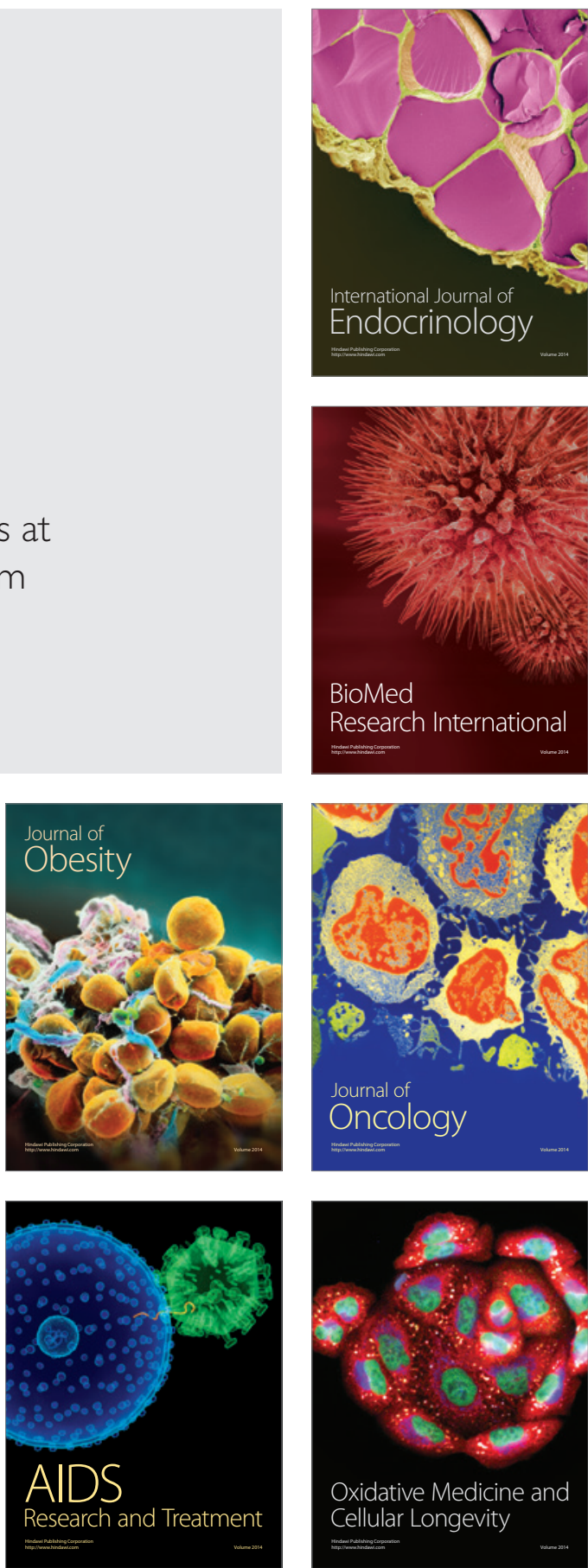